\title{
DISAPPEARING BORDERS IN THE VISEGRAD COUNTRIES
}

\section{Ádám Márkus*}

\begin{abstract}
The aim of this paper is to evaluate the trade integration process of the Visegrad countries from a special point of view, namely by estimating border effects in the countries. The regressional analysis run with two different estimators (OLS vs. PPML) on two different model specifications suggests that between 1995 and 2011 the V4 countries were integrating continuously into the Single Market of the European Union. The results also show that the size of border effect is fairly sensitive to the estimator and particularly to the specification chosen by the researcher. According to the country-level estimation, Hungary seems to be the most integrated country getting the lowest home bias parameters followed by the Czech Republic, Slovakia and Poland, respectively.
\end{abstract}

Keywords: border effect, Visegrad countries, gravity model, market integration, PPML JEL Classification: F14, F15

\section{Introduction}

Since the middle of the 1990s a growing number of researchers have been interested in examining border effects that is comparing domestic merchandise trade flows with international ones within the framework of gravity models. It has been pointed out that borders still have a determining role in hindering cross country trade interactions. Generally the literature states that theoretically the national market is the most integrated one; hence it can be used as a benchmark when one examines the level of international market fragmentation. It is a well-known fact since McCallum's (1995) famous seminal paper that international markets are far from perfect integration, countries show an excessive favour towards domestic trading partners even during today's accelerating globalization. Moreover, studies in connection with the US States (Wolf, 2000; Millimet and Osang, 2007; Coughlin and Novy, 2013; inter alia) and the European Union member countries (Head and Mayer, 2000, 2002; Nitsch. 2000; Chen. 2004; Pacchioli, 2011; inter alia) emphasized, that this phenomenon called border effect exists even within the most integrated regions of the world, although the magnitude of that seems to be sensitive to different model specifications.

Studying the time trend of border effect gives the opportunity to evaluate the integration process of international markets. Helliwell (1998) for instance demonstrated that the Canada-US border effect was declining during the period of 1988-1996 (from around

* Ádám Márkus, Faculty of Economics and Business Administration, University of Debrecen, Debrecen, Hungary (adam.markus@econ.unideb.hu).

This research was partially supported by the Pallas Athéné Domus Scientiae Foundation (Project No.: SZ/0215/2015). The views expressed are those of the author's and do not necessarily reflect the official opinion of the Pallas Athéné Domus Scientiae Foundation. 
22 to 11) as a sign of deepening integration. In line with the development of the European integration the number of empirical investigations in the connection with the presence and evolution of border effect in Europe has grown rapidly, as well. Working with panel data Head and Mayer (2000) could point out a kind of development in the European internal market when they estimated the evolution of border effect among 9 member countries through the 1980s. Although it is a cross sectional analysis we can draw some useful conclusions from Chen's (2004) work as well. According to her results the older EU members like Germany or the United Kingdom showed much smaller border effect in 1996 than the recently joined Finland. On the whole, it is ascertainable that European countries show a huge bias towards domestic trade before or in the beginning of their EU membership. However, after the adaptation to the new system and becoming a member of the community border effect is usually decreasing year by year as a sign of deepening market integration.

By examining the Central and Eastern European (CEE) region from this regard is able to contribute to the literature. Although a respectable number of researchers have dealt with the post socialist transformation of these countries, just a minority of them (Cheptea, 2010; Pásztor, 2014) have focussed directly on border effect estimations using the gravity model so far. Horvath et al. (2008) for instance approached this problem through the fulfilment of the law of one price. Accordingly, this paper introduces the trade integration process of the Visegrad countries into the European Union through a border effect estimation. Furthermore, to raise robustness it compares two different model specifications (time invariant individual and time fixed effects versus time varying individual and country pair fixed effects) and two different estimators (ordinary least squares versus Poison pseudo-maximum likelihood). The remainder of the paper is the following. The next section describes a theoretical basis for border effect estimation. The third section clarifies the methodological problems. Section 4 introduces the exact model specification and the data. Then, in Section 5 the main results and findings are interpreted. Finally, the last part concludes the remarks of the paper.

\section{Theoretical Background - Border Effect and the Gravity Model}

In a frictionless world economy the ratio of domestic to foreign goods in domestic consumption has to be identical to the ratio of domestic production to world production (Balta and Delgado, 2007). In reality, however, countries show an excessive favour towards domestic products, which has two main reasons: income inequality and border related transaction costs. Samuelson (1954) already admonishes that transaction costs can trigger substantial home bias in consumption. McCallum (1995) also demonstrates a huge home bias in trade which he calls border effect. Based on data from 1988, the author claims that a Canadian province trades with another province 22 times more than it would do with an American state of the same economic size and equidistant from it. His questionable finding launches a comprehensive sub-literature in order to solve one of the major puzzles in international macroeconomics as Obstfeld and Rogoff (2001) designate it. These facts suggest that after controlling incomes, distances and other costs of international transactions or looking at deeply integrated regions one should observe that state borders themselves have minor role in international merchandise trade interactions. 
To estimate the size of over-preference of domestic trade partners correctly one should first look at the evolution of the gravity model through recent decades. The model has been the most successful and reliable tool for a long time to examine the determinants of international merchandise trade flows. The general framework Equation 1 developed by Tinbergen (1962) and Pöyhönen (1963) provides significant relationship among economic sizes $\left(Y_{i}, Y_{j}\right)$, geographical distance $\left(D_{i j}\right)$ and values of bilateral trade flows $\left(T_{i j}\right)$. As far as in the early years of existence numerous empirical investigations were motivated by the strong explanatory power of the model notwithstanding that those specifications were mostly based on physics rather than economics.

$$
T_{i j}=A Y_{i}^{\gamma} Y_{j}^{\delta} D_{i j}^{\theta}
$$

The first microeconomic derivation of the gravity model came by Anderson (1979), who supposed perfect competition and worked with the so called Armington assumption, that is, products are differentiated by country of origin. According to this approach, in equilibrium the national income of a country equals the sum of the demand for domestic and foreign goods. Hence the bigger a country's economic mass the more goods it exports and imports (i.e. the expected sign of $\gamma$ and $\delta$ in Equation 1 is positive). In addition, the 'gravitational' pull of a country weakens as the distance (cost of transportation) increases between the trading partners (i.e. the expected sign of $\theta$ in Equation 1 is negative) because part of the value of the traded goods melts away (Samuelson, 1954). After Anderson, some other foundations were revealed showing that the gravity equation can be derived from a wide range of trade theories. Krugman (1980) and Bergstrand (1985, 1989) considered increasing returns and monopolistic competition as the theoretical basis, while Deardorff (1998) showed that bilateral trade based on differences in factor endowments can be also described with Tinbergen's and Pöyhönen's basic concept. Furthermore, it was confirmed by Eaton and Kortum (2002) that the gravity equation can be a reduction of a classical Ricardian international trade model, as well. All in all, it should be noticed that all of the derivations have something in common. They all use a general equilibrium approach of the international trade in the final goods sector.

In a more recent and widely cited theoretical concept Anderson and van Wincoop (2003) warned researchers that earlier theoretical derivations and thus empirical papers based upon them did not consider some important factors called multilateral trade resistance terms. Namely, the pattern of trade between two given countries depends on the size of bilateral trade barriers relative to the average trade barriers in the world, too. According to their findings, these complex price (or resistance) terms are unobservable, however, can be subscribed as a system of equations including variables having exact values such as distance, border-related transaction costs and relative incomes. The following Equation 2 shows the theoretically consistent gravity equation:

$$
x_{i j}=\frac{Y_{i} Y_{j}}{Y^{w}}\left(\frac{t_{i j}}{P_{i} P_{j}}\right)^{1-\sigma},
$$


where $x_{i j}$ means merchandise export flows from country $i$ to country $j . Y_{i}, Y_{j}, Y^{w}$ are nominal incomes of countries $i, j$ and the world respectively. $P_{i}$ and $P_{j}$ denote the multilateral resistance terms for country $i$ and country $j$. Finally, $t_{i j}$ represents trade costs between the two countries $i$ and $j$. The trade cost variable can be further divided as it seems to be a function of distance, adjacency, cultural similarity, regional trade agreements, common currency and the home bias.

\section{Methodological Issues}

As the gravity theory suggests a cross-sectional bilateral linkage between trade and some other factors, in the first several decades econometrics mainly covered log-linearized cross-sectional estimation using ordinary least squares. Since the early 2000s, however, this basic approach has become open to some criticism. Most frequently, omitted variables are cast up against them. Although most microeconomic derivations attract attention for the role of prices or price indexes, econometric specifications initially ignored them by choice or because of limited access to such data. To account for the omitted price terms Anderson and van Wincoop (2003) suggest a difficult non-linear specification and point out why and to what extent McCallum (1995) overestimates the size of border effect between Canada and the United States. Rose and van Wincoop (2001) and Feenstra (2002), on the other hand, recommend a more familiar way to deal with multilateral trade resistance, specifically the inclusion of a dummy for the origin and one for the destination country. This specification also controls for the unobservable resistance terms and thus obviates the bias caused by omitted variables. A further development of the Anderson - van Wincoop model comes from Baier and Bergstrand (2009) who emphasize the drawback of region-specific fixed effects, namely that they preclude comparative-static analysis. The authors provide evidence that the Anderson - van Wincoop derivation can be transformed by a first-order Taylor series expansion to an equation which involves multilateral and world resistance terms explicitly and still can be estimated by OLS.

More recently, cross-sectional estimations have been increasingly substituted for panel data methods in order to involve time dimension, have more observations and more accurate results. An obvious way to estimate panel data regressions is the fixed or random effect estimator. Within the gravity literature the fixed effects model is preferred using individual and time specific effects. Time invariant country pair dummies what the basic method suggests, however, impede researchers to estimate the effect of a variable that does not vary over time. This problem led Hilberry and Hummels (2003) and Pacchioli (2011) to utilize the framework of Mátyás (1997). They include origin and destination fixed effects together with time dummies to estimate border effect, which is a time invariant factor in their specification. Whereas, Cheng and Wall (2005) argue that Mátyás' (1997) specification is a restricted version of the classic fixed effect estimator with country pair dummies. In their empirical example they compare alternative fixed effect models out of which the one with pair fixed effects seems to give the most accurate results with the smallest standard errors. Baldwin and Taglioni (2006) also favour country pair dummies as they are able to control for idiosyncratic bilateral factors influencing trade interactions. Namely, countries 
trade dissimilarly with different countries. This is even true for the same country pair but in a different direction, that is $d_{u m m y_{i j}}$ is not equal to $d u m m y_{j i}$. Note, however, that Cheng and Wall (2005) as well as Baldwin and Taglioni (2006) do not focus on border effects. Andresen (2010) in turn estimates the Canada-US border effect with panel data using pair and time fixed effects. Border dummies broken down annually and provincially allows the author to use pair dummies along with border dummies. In such a case, however, as Baldwin and Taglioni (2006) points out, the parameter of the border dummy reflects the trade impact of the border arisen just from the time variation of the variable as the cross sectional part of its effect is captured by the coefficient of the pair dummy ${ }^{1}$.

As it was already mentioned, the original econometric specification of the gravity model is in log-linear form. Santos Silva and Tenreyro (2006), however, confirm that in the presence of heteroskedasticity OLS estimation is biased due to Jensen's inequality that is the expected value of the logarithm is not equal to the logarithm of the expected value. They propose to leave the model in its multiplicative form and use the Poison pseudomaximum likelihood (PPML) estimator to get consistent estimates. In addition, this method allows the researcher to involve all possible observations within the sample even those with zero trade flows as no logarithmic transformation is needed.

To examine the evolution of border effect in the Visegrad countries and draw real conclusions from the estimation it is worth considering all these theoretical and econometric milestones.

\section{Model Specification and Data Description}

To increase robustness two different fixed effect regressions and two different estimators (OLS and PPML) are utilized and compared. As the theoretical literature suggests multilateral trade resistance is always controlled for by defining separate dummies for the origin and destination country. The first specification (henceforth Mátyás (1997) specification) follows the idea of Mátyás (1997), Hilberry and Hummels (2003) and Pacchioli (2011) that is exporter and importer dummies are included along with year fixed effects. Equation 3 show the model estimated by OLS while Equation 4 is the estimable equation for PPML.

$$
\begin{aligned}
& \ln X_{i j t}=\beta_{0}+\beta_{1} \ln Y_{i t}+\beta_{2} \ln Y_{j t}+\beta_{3} \ln P_{o p_{i t}}+\beta_{4} \ln P_{o p_{j t}}+\beta_{5} \ln D_{i j}+\beta_{6} a d j_{i j}+ \\
& +\beta_{7} \text { cur }_{i j t}+\sum_{k=1996}^{2011} \alpha_{k}+\sum_{i=2}^{26} \alpha_{i}+\sum_{j=2}^{26} \alpha_{j}+\sum_{k=1995}^{2011}\left(\sum_{c}\right) \text { hom } e_{k}+\varepsilon_{i j t} \\
& X_{i j t}=\exp \left\{\begin{array}{l}
\beta_{0}+\beta_{1} \ln Y_{i t}+\beta_{2} \ln Y_{j t}+\beta_{3} \ln P_{o p}+\beta_{4} \ln P o p_{j t}+\beta_{5} \ln D_{i j}+\beta_{6} a d j_{i j}+ \\
+\beta_{7} c u r_{i j t}+\sum_{k=1996}^{2011} \alpha_{k}+\sum_{i=2}^{26} \alpha_{i}+\sum_{j=2}^{26} \alpha_{j}+\sum_{k=1995}^{2011}\left(\sum_{c}\right) \text { hom } e_{k}+\varepsilon_{i j t}
\end{array}\right\},
\end{aligned}
$$

$X_{i j t}$ is the current dollar value of export flows from country $i$ to country $j$ in period $t$. $Y_{i t}$ and $Y_{j t}$ mean the gross domestic products in current dollars of the exporter and importer countries respectively in year $t$. $P o p_{i t}$ and $P o p_{j t}$ are the sizes of population in the two

1 Although Baldwin and Taglioni (2006) estimate the trade effect of the Eurozone, the econometric problem is the same. 
countries. Costs of transportation are captured with four variables: distance and dummies for common land border, common currency and border effect. $D_{i j}$ stands for bilateral distance while $a d j_{i j}$ is the dummy for adjacency that takes the value of 1 if $i$ and $j$ have a common land border and 0 otherwise. The $c u r_{i j}$ dummy is included to control for the effect of sharing the same currency, although it has to be mentioned that any kind of impact can arise just from the Eurozone membership of the Slovak Republic after 2009. Turning to the remaining variables, $\alpha_{k}$ is the time specific fixed effect which controls for all factors that are identical across countries but change over time. $\alpha_{i}$ and $\alpha_{j}$ are the individual country fixed effects that contain country specific factors that vary across the countries but are constant over time. Multilateral trade resistance terms are also included in these dummies. It is worth noting that to avoid perfect collinearity less fixed effects were added then both the number of countries and that of years. The factor of interest is border effect for which binary variables $\left(\right.$ home $_{k}$ ) are defined which get the value of 1 if $i=j$ in year $k$. In addition, border dummies are involved into the equation in two different manner. On the one hand,

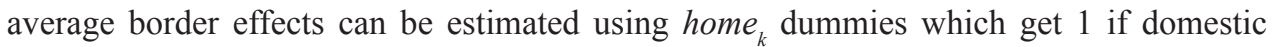
trade is observed in any of the four Visegrad countries in year $k$. On the other hand, when we are interested in individual border effects separate home dummies are involved for every single Visegrad country $c(c=\{$ the Czech Republic, Hungary, Poland, Slovakia $\})$. The disaggregated home bias variables allow us to make not just temporal but also spatial comparisons within the examined region. Finally, there is an error term assumed to be a white noise $\left(\varepsilon_{i j t} \sim N\left(0, \sigma^{2}\right)\right)$.

On the other hand, another specification a' la Baldwin and Taglioni (2006) is also utilized (henceforth Baldwin and Taglioni (2006) specification) where time invariant country pair fixed effects are included along with time varying exporter and importer dummies. Equation 5 and Equation 6 represent the models for the second specification estimated by OLS and PPML, respectively.

$$
\begin{aligned}
& \ln X_{i j t}=\beta_{0}+\beta_{1} \text { cur }_{i j t}+\sum_{i j=2}^{192} \alpha_{i j}+\sum_{i k=2}^{399} \alpha_{i k}+\sum_{j k=2}^{399} \alpha_{j k}+\sum_{k=1996}^{2011}\left(\sum_{c}\right) \text { hom } e_{k}+\varepsilon_{i j t} \\
& X_{i j t}=\exp \left\{\beta_{0}+\beta_{1} \text { cur }_{i j t}+\sum_{j=2}^{192} \alpha_{j}+\sum_{k=2}^{399} \alpha_{k}+\sum_{k=2}^{399} \alpha_{k}+\sum_{k=1996}^{2011}\left(\sum_{c}\right) \text { hom } e_{k}+\varepsilon_{i j t}\right\}
\end{aligned}
$$

$\alpha_{i j}$ is the country pair specific fixed effect which is time invariant. It is included to control for country pair heterogeneity. $\alpha_{i k}$ and $\alpha_{j k}$ are time varying exporter and importer country dummies, respectively. Their elemental role is to count for multilateral trade resistance. The other variables are identical to those explained above. Note that GDPs and population variables as well as distance and adjacency are omitted since they are absorbed either by the country pair or the exporter/importer dummies.

\section{Description of data}

Turning to the data, the first step to build the dataset for the investigation was to define the volume of domestic trade flows which is one of the most problematic points of border effect estimation in connection with European countries as unlike the United States there 
are no statistics published on this level ${ }^{2}$. Wei (1996) however, presented a solution for this puzzle showing the way for further European border effect studies. According to his method our point of origin is that domestic trade flows can be approximated well, when one subtracts total merchandise export from total goods production. To calculate that, a four-step procedure has to be followed. First, as we are focussing on commodity trade the goods part of GDP needs to be defined. Using data from the World Development Indicators database services and some other units have to be extracted from total output. ${ }^{3}$ The second task is to compute the shipment to value added ratio because GDP is defined in value added terms, while export data are recorded in shipment values. To get that step the value of production has to be divided by the value added at factor costs (data are collected from the World InputOutput Database [WIOD]). By the third step we can get total goods production of a country in shipment value as the product of the goods part of GDP and the shipment to value added ratio. Finally, subtracting total export of goods from total goods production yields the value of intra-national trade flows.

The time dimension of our study is determined by this procedure. Domestic trade flows and necessarily border effects are estimated through the period of 1995-2011 because of the extent of the WIOD database.

As for the country pair observations, export flows were collected from each Visegrad country to each EU member country and also from the opposite direction, while domestic commodity flows of each Visegrad country was computed regarding the method described afore. Accordingly, only those observations constitute our sample where a Visegred country appears as country $i$, country $j$ or both. The source of bilateral export data is the UN Comtrade Database. It has to be mentioned, that Belgium and Luxembourg were contracted and handled as one country during the sample period, because they were considered as one statistical unit in the database before 1999, so working with them separately would be quite problematic in the early years of the sample. Our panel dataset has 8 missing export observations concerning Bulgaria and Malta in the year of 1995. Hence, during OLS estimation I use a truncated sample of 3,256 observations out of the maximum 3,264. However, the PPML estimator allows to involve all possible data points even those with zero trade flows.

Data for the economic mass, that is GDP and population, come from the World Bank World Development Indicators database. Distance data were collected from the CEPII Geodist database, which is a comprehensive data collection from 224 countries on internal and bilateral distances, and even on popular gravity dummies like adjacency, common currency, common language, common historical past, etc. Both bilateral and domestic distances are defined - following Head and Mayer (2002) - as weighted harmonic average distances of the most populated cities.

2 The only exception in this regard is Spain. Gil-Pareja et al. (2005) and Llano-Verduras et al. (2011) could estimate border effects using detailed provincial data.

3 As services and etc. are observed as value added \% of GDP the exact formula for this step is: GDP*(1-services\%/100). 


\section{Results}

Results are introduced using 4 different tables. Table 1 presents parameter estimates for

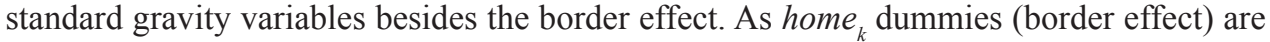
the variables of interest their coefficients which came from the same regressions as that in Table 1 are listed separately in Tables 2, 3 and 4.

Results in Table 1 are broken down into 8 columns as two specifications, two estimators and two types of border dummy are considered. Notice that in the specification following Baldwin and Taglioni (2006) there are no results presented for variables like GDP, population, distance and adjacency (columns 5-8) because they are omitted due to the inclusion of time varying nation dummies and time invariant country pair effects. However, in columns 1-4 (Mátyás (1997) specification) one can look at what happens when different estimators are used.

OLS estimation (columns 1 and 2) yields quite small income elasticities. A 1\% increase in the exporter's GDP means about a $0.7 \%$ increase in trade intensity, while enhancing the income of the importer's country by $1 \%$ raises bilateral exports by $0.4 \%$ on average. While the importers population seems to be an insignificant factor the exporter's population strongly discourages international transactions with an elasticity of -3.62 or -3.66 . The distance variable got the conventional negative coefficient fairly close to unity. If two partners are located 1\% further from each other the volume of trade is $1.3 \%$ less on average. Contiguity and using a common currency also significantly contribute to deepen international trade relations. Two countries trade $40 \%$ or $12 \%$ more on average, if they are adjacent or use the same currency ceteris paribus.

However, as Santos Silva and Tenreyro (2006) highlight using OLS on data in natural logarithms results in some statistical bias. This bias is reflected in the parameters of columns 1 and 2. Estimating the regressions by PPML shelters against the statistical bias and leads to considerably different coefficients (columns 3 and 4 in Table 1). One of the most outstanding differences is that importer's population becomes statistically significant with a massive positive impact on trade when switching from OLS to PPML, while the strongly negative role of exporter's population weakens by a considerable extent. As far as geographical proximity is concerned, its elasticity which - in case of OLS - is escalated due the heteroskedasticity of the error term falls under unity. Contiguity seems to have no significant effect on exports when using the PPML estimator. Income elasticities, however, are quite similar to the OLS case, a 1\% increase in the exporter's GDP means about a $0.7 \%$ increase in trade intensity, while enhancing the income of the importer country by $1 \%$ raises exports by $0.4-0.5 \%$ on average. Sharing the euro as a common currency has just a slight influence on trade flows. Its positive and significant effect becomes significantly negative after the OLS estimator is substituted by PPML. Finally, as Santos Silva and Tenreyro (2006) also emphasize, PPML outperforms OLS regarding the goodness of fit, too (0.980.99 versus 0.96$)$.

In the second specification - following Baldwin and Taglioni (2006) - time invariant country pair fixed effects are involved along with time varying origin and 
destination dummies (columns 5-8 in Table 1). This approach allows to control for both multilateral resistance and country pair heterogeneity supporting the avoidance of all possible bias triggered by omitted variables. This is also reflected in the extremely high $R^{2}$ values (0.99-1.00). The drawback of this procedure, however, is that only those variables can be estimated that change over time and are specific to country pairs that is currency union and border effect dummies broken down annually. All potential effects of the other variables are absorbed by the fixed effects. This specification again predicts small and hardly or not significant effects for the common currency.

Table 1 | Results of Standard Gravity Variables when Different Specifications and Border Fffect Variables Are Utilized

\begin{tabular}{|c|c|c|c|c|c|c|c|c|}
\hline \multirow{3}{*}{$\begin{array}{l}\text { Dep. var.: } \\
\text { In } X_{i j}(\mathrm{OLS}) ; \\
X_{i j} \text { (PPML) }\end{array}$} & \multicolumn{4}{|c|}{ Mátyás (1997) specification } & \multicolumn{4}{|c|}{ Baldwin and Taglioni (2006) specification } \\
\hline & \multicolumn{2}{|c|}{ OLS } & \multicolumn{2}{|c|}{ PPML } & \multicolumn{2}{|c|}{ OLS } & \multicolumn{2}{|c|}{ PPML } \\
\hline & $\begin{array}{l}\text { (1) } \\
\text { V4 }\end{array}$ & $\begin{array}{c}\text { (2) } \\
\text { Individual }\end{array}$ & $\begin{array}{l}\text { (3) } \\
\text { V4 }\end{array}$ & $\begin{array}{c}\text { (4) } \\
\text { Individual }\end{array}$ & $\begin{array}{l}\text { (5) } \\
\text { V4 }\end{array}$ & $\begin{array}{c}\text { (6) } \\
\text { Individual }\end{array}$ & $\begin{array}{l}\text { (7) } \\
\text { V4 }\end{array}$ & $\begin{array}{c}(8) \\
\text { Individual }\end{array}$ \\
\hline $\ln Y_{i}$ & $\begin{array}{c}0.67^{\star * *} \\
(0.089)\end{array}$ & $\begin{array}{l}0.67^{* * *} \\
(0.09)\end{array}$ & $\begin{array}{c}0.69^{\star * *} \\
(0.106)\end{array}$ & $\begin{array}{c}0.66^{\star * *} \\
(0.086)\end{array}$ & - & - & - & - \\
\hline $\ln Y_{j}$ & $\begin{array}{c}0.38^{* * *} \\
(0.078)\end{array}$ & $\begin{array}{c}0.37^{\star * *} \\
(0.079)\end{array}$ & $\begin{array}{c}0.53^{* \star *} \\
(0.105)\end{array}$ & $\begin{array}{c}0.5^{\star * *} \\
(0.085)\end{array}$ & - & - & - & - \\
\hline $\ln P_{o p}$ & $\begin{array}{l}-3.62^{* * *} \\
(0.455)\end{array}$ & $\begin{array}{l}-3.66^{\star * *} \\
(0.463)\end{array}$ & $\begin{array}{l}-1.95^{\text {***}} \\
(0.672)\end{array}$ & $\begin{array}{l}-1.77^{* * *} \\
(0.481)\end{array}$ & - & - & - & - \\
\hline $\operatorname{In} P_{o p}$ & $\begin{array}{c}0.27 \\
(0.413)\end{array}$ & $\begin{array}{c}0.23 \\
(0.417)\end{array}$ & $\begin{array}{c}2.2^{* * *} \\
(0.672)\end{array}$ & $\begin{array}{l}2.25^{* * *} \\
(0.44)\end{array}$ & - & - & - & - \\
\hline $\ln D_{i j}$ & $\begin{array}{c}-1.25^{\star \star \star} \\
(0.05)\end{array}$ & $\begin{array}{l}-1.31^{* * *} \\
(0.051)\end{array}$ & $\begin{array}{l}-0.57^{* * *} \\
(0.073)\end{array}$ & $\begin{array}{l}-0.95^{\star \star *} \\
(0.066)\end{array}$ & - & - & - & - \\
\hline$a d j_{i j}$ & $\begin{array}{c}0.34^{* * *} \\
(0.043)\end{array}$ & $\begin{array}{c}0.3^{* * *} \\
(0.425)\end{array}$ & $\begin{array}{c}0.05 \\
(0.052)\end{array}$ & $\begin{array}{c}0.05 \\
(0.045)\end{array}$ & - & - & - & - \\
\hline cur $_{i j}$ & $\begin{array}{c}0.11^{* *} \\
(0.051)\end{array}$ & $\begin{array}{c}0.12^{* *} \\
(0.052)\end{array}$ & $\begin{array}{l}-0.14^{* * *} \\
(0.049)\end{array}$ & $\begin{array}{l}-0.08^{* *} \\
(0.041)\end{array}$ & $\begin{array}{c}-0.06 \\
(0.066)\end{array}$ & $\begin{array}{c}-0.07 \\
(0.066)\end{array}$ & $\begin{array}{l}0.12^{\star *} \\
(0.05)\end{array}$ & $\begin{array}{c}0.06 \\
(0.046)\end{array}$ \\
\hline const & $\begin{array}{l}53.18^{* * *} \\
(11.87)\end{array}$ & $\begin{array}{l}55.16^{\text {*** }} \\
(12.047)\end{array}$ & $\begin{array}{l}-10.36 \\
(8.454)\end{array}$ & $\begin{array}{c}-12.62^{* *} \\
(4.99)\end{array}$ & $\begin{array}{l}21.25^{\star * *} \\
(0.142)\end{array}$ & $\begin{array}{l}21.26^{\star * *} \\
(0.145)\end{array}$ & $\begin{array}{l}-1.76^{* * *} \\
(0.165)\end{array}$ & $\begin{array}{c}-1.63^{* * *} \\
(0.16)\end{array}$ \\
\hline $\mathbf{N}$ & 3,256 & 3,256 & 3,264 & 3,264 & 3,256 & 3,256 & 3,264 & 3,264 \\
\hline$R^{2}$ & 0.957 & 0.959 & 0.981 & 0.996 & 0.987 & 0.987 & 0.999 & 1.000 \\
\hline RMSE & 0.485 & 0.482 & 0.193 & 0.081 & 0.318 & 0.320 & 0.040 & 0.023 \\
\hline
\end{tabular}

Notes: $\boldsymbol{R}^{\mathbf{2}}$ represents the goodness of fit, $\mathbf{N}$ stands for the number of observations, and RMSE declares the root mean squared error. ${ }^{* *},{ }^{* *}$ mean that the parameters are significant at $1 \%$ or $5 \%$ level, respectively. The standard errors are listed in parenthesis. Const is an abbreviation for the constant term. Exporter, importer, country pair and year fixed effects as well as border effects are not presented for brevity.

Source: Author's calculation 


\section{Spatial and temporal analysis of border effects}

The main purpose of this paper is to study the evolution of border effect in the Visegrad countries not just on an average but also on a single country level as such empirics are fairly scarce in this region. Hence, some useful consequences can be drawn regarding the trade integration process of the countries into the single market of the European Union.

Table 2 shows the evolution of the average border effect in the four Visegrad countries. In this case the home $e_{k}$ dummy get the value of 1 when domestic trade is observed in any of the four countries in year $k$ and zero otherwise. The estimated coefficients need to be handled as elasticities. The figures refer to the atypical nature of domestic trade that is they show the extent of extreme preference for domestic trade partners. For instance, based on the first specification (columns 1-2), an average Visegrad country traded in 199521.1 $\left(\mathrm{e}^{3.05}\right)$ or $32.8\left(\mathrm{e}^{3.49}\right)$ times more within its borders than it should have normally done regarding the gravity model. These numbers suggest that in the beginning of the examined period the trade patterns of the V4 countries were characterised by a huge home bias. In 2011, however, the excessive preference of domestic trade was just $2.1\left(\mathrm{e}^{0.74}\right)$ or $5.64\left(\mathrm{e}^{1.73}\right)$ fold depending on which estimator is used. The decreasing trend can be clearly seen over time. In the beginning of the period exporters of the Visegrad countries had to face extremely large border effect, during the years, however, the priority of domestic partners were decreasing significantly resulting from the favourable tendencies in the world economy and of course the EU accession. The results project forward that international markets between the European Union and the Central and Eastern European region are being bound continually tighter and tighter.

Looking at columns 3 and 4 of Table 2 one may be astonished about the negative and mostly significant border effect parameters. The figures suggest that the obstructing role of borders completely disappeared. What is more, they rather induce trade. After the turn of the millennium the firms in the V4 countries unambiguously favoured foreign partners against domestic ones. In 2000 for example, an arbitrary Visegrad country traded with domestic partners just $50.1 \%$ (OLS) or $61.9 \%$ (PPML) of what it would have done with an EU member country of the same economic size and located at a distance equal to that of the domestic market. These strict conclusions are exactly the opposite of what we can draw from the first specification. Thus the effect of state borders for international trade flows might be confusing. One important note, however, should be mentioned here. As Baldwin and Taglioni (2006) also emphasize, the coefficients of the pair specific variables like common currency or border effect are identified only on the time variation of the variables as the cross-sectional parts of their impact are merged into the pair dummies. Therefore these variables work actually promptly if there is a significant time variation in them. As one particular border effect variable varies just several times during the sample period the regression can hardly distinguish between the time invariant pair dummies and the barely time varying border effects. 
Table 2 | Estimated Coefficients of Average Border Effect Dummies

\begin{tabular}{|c|c|c|c|c|}
\hline \multirow{2}{*}{$\begin{array}{l}\text { Dep. var.: } \\
\text { In } X_{i j}(\mathrm{OLS}) ; \\
X_{i j}(\mathrm{PPML})\end{array}$} & \multicolumn{2}{|c|}{ Mátyás (1997) specification } & \multicolumn{2}{|c|}{ Baldwin and Taglioni (2006) specification } \\
\hline & $\begin{array}{l}\text { (1) } \\
\text { OLS }\end{array}$ & $\begin{array}{c}\text { (2) } \\
\text { PPML }\end{array}$ & $\begin{array}{l}\text { (3) } \\
\text { OLS }\end{array}$ & $\begin{array}{c}\text { (4) } \\
\text { PPML }\end{array}$ \\
\hline home1995 & $\begin{array}{l}3.05^{* * *} \\
(0.217)\end{array}$ & $\begin{array}{c}3.49 * * * \\
(0.147)\end{array}$ & - & - \\
\hline home1996 & $\begin{array}{l}3.07^{* * *} \\
(0.239)\end{array}$ & $\begin{array}{l}3.44^{* * *} \\
(0.143)\end{array}$ & $\begin{array}{c}0.04 \\
(0.32)\end{array}$ & $\begin{array}{c}0.09 \\
(0.284)\end{array}$ \\
\hline home1997 & $\begin{array}{c}2.78^{* * *} \\
(0.223) \\
\end{array}$ & $\begin{array}{c}3.18^{* * *} \\
(0.135) \\
\end{array}$ & $\begin{array}{l}-0.26 \\
(0.25) \\
\end{array}$ & $\begin{array}{c}-0.18 \\
(0.264)\end{array}$ \\
\hline home1998 & $\begin{array}{c}2.6^{* * *} \\
(0.239) \\
\end{array}$ & $\begin{array}{c}3^{* * *} \\
(0.13) \\
\end{array}$ & $\begin{array}{l}-0.4^{*} \\
(0.237)\end{array}$ & $\begin{array}{c}-0.27 \\
(0.247)\end{array}$ \\
\hline home1999 & $\begin{array}{l}2.47^{* * *} \\
(0.215)\end{array}$ & $\begin{array}{l}2.92^{* * *} \\
(0.132)\end{array}$ & $\begin{array}{l}-0.46^{*} \\
(0.238)\end{array}$ & $\begin{array}{c}-0.26 \\
(0.242)\end{array}$ \\
\hline home2000 & $\begin{array}{c}2.2^{* * * *} \\
(0.249) \\
\end{array}$ & $\begin{array}{c}2.7^{* * * *} \\
(0.129) \\
\end{array}$ & $\begin{array}{l}-0.68^{* * *} \\
(0.246) \\
\end{array}$ & $\begin{array}{l}-0.48^{* *} \\
(0.239) \\
\end{array}$ \\
\hline home2001 & $\begin{array}{l}2.02^{* * *} \\
(0.238)\end{array}$ & $\begin{array}{c}2.6^{* * *} \\
(0.126)\end{array}$ & $\begin{array}{l}-0.8^{* * *} \\
(0.232)\end{array}$ & $\begin{array}{l}-0.55^{* *} \\
(0.236)\end{array}$ \\
\hline home2002 & $\begin{array}{c}1.93^{* * *} \\
(0.254)\end{array}$ & $\begin{array}{c}2.45^{* * *} \\
(0.127)\end{array}$ & $\begin{array}{l}-0.93^{* * *} \\
(0.243)\end{array}$ & $\begin{array}{l}-0.7^{* * *} \\
(0.235)\end{array}$ \\
\hline home2003 & $\begin{array}{l}1.85^{* * *} \\
(0.239)\end{array}$ & $\begin{array}{c}2.4^{* * *} \\
(0.126)\end{array}$ & $\begin{array}{l}-1.06^{* * *} \\
(0.219)\end{array}$ & $\begin{array}{l}-0.79 * * * \\
(0.229)\end{array}$ \\
\hline home2004 & $\begin{array}{c}1.72^{* * *} \\
(0.235)\end{array}$ & $\begin{array}{c}2.33^{* * *} \\
(0.127) \\
\end{array}$ & $\begin{array}{l}-1.29 * * * \\
(0.221)\end{array}$ & $\begin{array}{c}-1^{* * *} \\
(0.229) \\
\end{array}$ \\
\hline home2005 & $\begin{array}{l}1.62^{* * *} \\
(0.248)\end{array}$ & $\begin{array}{l}2.23^{* * *} \\
(0.123)\end{array}$ & $\begin{array}{l}-1.44^{* * *} \\
(0.221)\end{array}$ & $\begin{array}{l}-1.14^{* * *} \\
(0.228)\end{array}$ \\
\hline home2006 & $\begin{array}{l}1.39 * * * \\
(0.304)\end{array}$ & $\begin{array}{l}2.09^{* * * *} \\
(0.128) \\
\end{array}$ & $\begin{array}{c}-1.69^{* * *} \\
(0.23) \\
\end{array}$ & $\begin{array}{l}-1.36^{* * *} \\
(0.228)\end{array}$ \\
\hline home2007 & $\begin{array}{l}1.25^{* * *} \\
(0.341)\end{array}$ & $\begin{array}{l}2.03^{* * *} \\
(0.134)\end{array}$ & $\begin{array}{l}-1.84^{* * *} \\
(0.245)\end{array}$ & $\begin{array}{l}-1.46^{* * *} \\
(0.229)\end{array}$ \\
\hline home2008 & $\begin{array}{l}1.28^{* * *} \\
(0.391)\end{array}$ & $\begin{array}{l}2.01^{* * *} \\
(0.129)\end{array}$ & $\begin{array}{l}-1.87^{* * *} \\
(0.245)\end{array}$ & $\begin{array}{l}-1.49 * * * \\
(0.231)\end{array}$ \\
\hline home2009 & $\begin{array}{c}1.33^{* * *} \\
(0.351)\end{array}$ & $\begin{array}{c}2.06^{* * *} \\
(0.131)\end{array}$ & $\begin{array}{l}-1.78^{* * *} \\
(0.244)\end{array}$ & $\begin{array}{l}-1.47^{* * *} \\
(0.228)\end{array}$ \\
\hline home2010 & $\begin{array}{c}0.98^{* * *} \\
(0.375)\end{array}$ & $\begin{array}{l}1.85^{* * *} \\
(0.15)\end{array}$ & $\begin{array}{c}-2.16^{* * *} \\
(0.26)\end{array}$ & $\begin{array}{l}-1.77^{* * *} \\
(0.229)\end{array}$ \\
\hline home2011 & $\begin{array}{c}0.74^{* *} \\
(0.371)\end{array}$ & $\begin{array}{l}1.73^{* * *} \\
(0.175)\end{array}$ & $\begin{array}{l}-2.44^{* * *} \\
(0.292)\end{array}$ & $\begin{array}{c}-2^{* * *} \\
(0.232)\end{array}$ \\
\hline
\end{tabular}

Notes: ${ }^{* *},{ }^{* *},{ }^{*}$ mean the $1 \%, 5 \%$ and $10 \%$ significance level, respectively. The standard errors are listed in parenthesis.

Source: Author's calculation

Although the numbers in the two specifications are apparently contradictory, one common conclusion flows from their decreasing trend that meets the goal of this paper. Namely, that the Visegrad countries were integrating continuously into the Single Market of the European Union since the hindering nature of borders were weakening year by year during the period of 1995-2011. The firms in the region were showing increasingly bigger favour toward foreign business partners. 
One further notice regarding the choice of the estimator can be mentioned, namely that regardless of the specification PPML results in respectively higher point estimates for border effect variables. This suggests that due to the statistical bias caused by logarithmic transformation one may underestimate the size of border effect using OLS.

Table 3 | Border Effect Coefficients Broken down by Country (Mátyás (1997) specification)

\begin{tabular}{|c|c|c|c|c|c|c|c|c|}
\hline \multirow{2}{*}{$\begin{array}{l}\text { Dep. var.: } \\
\ln X_{i j}(\mathrm{OLS}) ; \\
X_{i j}(\mathrm{PPML})\end{array}$} & \multicolumn{2}{|c|}{ Hungary } & \multicolumn{2}{|c|}{ Czech Republic } & \multicolumn{2}{|c|}{ Poland } & \multicolumn{2}{|c|}{ Slovakia } \\
\hline & $\begin{array}{l}\text { (1) } \\
\text { OLS }\end{array}$ & $\begin{array}{c}\text { (2) } \\
\text { PPML }\end{array}$ & $\begin{array}{l}\text { (3) } \\
\text { OLS }\end{array}$ & $\begin{array}{c}\text { (4) } \\
\text { PPML }\end{array}$ & $\begin{array}{l}\text { (5) } \\
\text { OLS }\end{array}$ & $\begin{array}{c}\text { (6) } \\
\text { PPML }\end{array}$ & $\begin{array}{l}\text { (7) } \\
\text { OLS }\end{array}$ & $\begin{array}{c}\text { (8) } \\
\text { PPML }\end{array}$ \\
\hline home1995 & $\begin{array}{l}2.43^{* * *} \\
(0.116)\end{array}$ & $\begin{array}{c}2.5^{* * *} \\
(0.134)\end{array}$ & $\begin{array}{l}2.69 * * * \\
(0.104)\end{array}$ & $\begin{array}{r}3^{* * *} \\
(0.101)\end{array}$ & $\begin{array}{l}3.09 * * * \\
(0.091)\end{array}$ & $\begin{array}{l}3.34^{* * *} \\
(0.122)\end{array}$ & $\begin{array}{l}3.57^{* * *} \\
(0.108)\end{array}$ & $\begin{array}{l}3.15^{* * *} \\
(0.108)\end{array}$ \\
\hline home1996 & $\begin{array}{c}2.4^{* * *} \\
(0.113)\end{array}$ & $\begin{array}{l}2.46^{* * *} \\
(0.134)\end{array}$ & $\begin{array}{l}2.73^{* * *} \\
(0.104)\end{array}$ & $\begin{array}{l}3.01^{* * *} \\
(0.101)\end{array}$ & $\begin{array}{c}3.03^{* * *} \\
(0.089)\end{array}$ & $\begin{array}{l}3.25^{* * *} \\
(0.114)\end{array}$ & $\begin{array}{c}3.7^{* * *} \\
(0.107)\end{array}$ & $\begin{array}{c}3.25^{* * *} \\
(0.101)\end{array}$ \\
\hline home1997 & $\begin{array}{l}2.06^{* * *} \\
(0.113)\end{array}$ & $\begin{array}{c}2.11^{* * *} \\
(0.133)\end{array}$ & $\begin{array}{l}2.51^{* * *} \\
(0.1)\end{array}$ & $\begin{array}{l}2.79 * * * \\
(0.103)\end{array}$ & $\begin{array}{l}2.84^{* * *} \\
(0.087)\end{array}$ & $\begin{array}{l}3.03^{* * *} \\
(0.112)\end{array}$ & $\begin{array}{l}3.29 * * * \\
(0.105)\end{array}$ & $\begin{array}{c}2.81^{* * * *} \\
(0.098)\end{array}$ \\
\hline home2000 & $\begin{array}{l}1.37^{* * *} \\
(0.112)\end{array}$ & $\begin{array}{c}1.48^{* * *} \\
(0.133)\end{array}$ & $\begin{array}{c}1.93^{* * *} \\
(0.099)\end{array}$ & $\begin{array}{l}2.25^{* * *} \\
(0.1)\end{array}$ & $\begin{array}{c}2.36 * * * \\
(0.086)\end{array}$ & $\begin{array}{l}2.61^{* * *} \\
(0.109)\end{array}$ & $\begin{array}{l}2.74^{* * *} \\
(0.104)\end{array}$ & $\begin{array}{c}2.28^{* * * *} \\
(0.093)\end{array}$ \\
\hline home2001 & $\begin{array}{c}1.2^{* * *} \\
(0.114)\end{array}$ & $\begin{array}{l}1.37^{* * *} \\
(0.129)\end{array}$ & $\begin{array}{c}1.79 * * * \\
(0.098)\end{array}$ & $\begin{array}{c}2.2^{* * *} \\
(0.096)\end{array}$ & $\begin{array}{c}2.19 * * * \\
(0.088)\end{array}$ & $\begin{array}{c}2.5^{* * *} \\
(0.106)\end{array}$ & $\begin{array}{l}2.51^{* * *} \\
(0.104)\end{array}$ & $\begin{array}{c}2.12^{* * * *} \\
(0.091)\end{array}$ \\
\hline home2002 & $\begin{array}{l}1.12^{* * *} \\
(0.114)\end{array}$ & $\begin{array}{c}1.26^{* * *} \\
(0.125)\end{array}$ & $\begin{array}{c}1.57^{* * *} \\
(0.097)\end{array}$ & $\begin{array}{c}1.94^{* * *} \\
(0.091)\end{array}$ & $\begin{array}{c}2.1^{* * *} \\
(0.086)\end{array}$ & $\begin{array}{c}2.39 * * * \\
(0.105)\end{array}$ & $\begin{array}{l}2.49 * * * \\
(0.102)\end{array}$ & $\begin{array}{l}2.07^{* * * *} \\
(0.088\end{array}$ \\
\hline home2003 & $\begin{array}{l}1.03^{* * *} \\
(0.115)\end{array}$ & $\begin{array}{l}1.17^{* * *} \\
(0.124)\end{array}$ & $\begin{array}{l}1.61 \text { *** } \\
(0.098)\end{array}$ & $\begin{array}{l}1.98^{* * *} \\
(0.09)\end{array}$ & $\begin{array}{c}2.03^{* * *} \\
(0.086)\end{array}$ & $\begin{array}{c}2.34^{* * *} \\
(0.108)\end{array}$ & $\begin{array}{l}2.33^{* * *} \\
(0.103)\end{array}$ & $\begin{array}{c}1.9 * * * \\
(0.084)\end{array}$ \\
\hline home2006 & $\begin{array}{l}0.29 \text { *** } \\
(0.11)\end{array}$ & $\begin{array}{l}0.56^{* * *} \\
(0.121)\end{array}$ & $\begin{array}{l}1.23^{* * *} \\
(0.097)\end{array}$ & $\begin{array}{c}1.67^{* * *} \\
(0.086)\end{array}$ & $\begin{array}{c}1.67^{* * *} \\
(0.083)\end{array}$ & $\begin{array}{l}2.07^{* * *} \\
(0.101)\end{array}$ & $\begin{array}{l}1.95^{* * *} \\
(0.102)\end{array}$ & $\begin{array}{c}1.61^{* * *} \\
(0.083)\end{array}$ \\
\hline home2007 & $\begin{array}{c}0 \\
(0.109)\end{array}$ & $\begin{array}{c}0.31^{* *} \\
(0.119)\end{array}$ & $\begin{array}{c}1.14^{* * *} \\
(0.097)\end{array}$ & $\begin{array}{c}1.59 * * * \\
(0.084)\end{array}$ & $\begin{array}{c}1.62^{* * *} \\
(0.081)\end{array}$ & $\begin{array}{c}2.05^{* * *} \\
(0.099)\end{array}$ & $\begin{array}{l}1.83^{* * *} \\
(0.101)\end{array}$ & $\begin{array}{c}1.52^{* * * *} \\
(0.082)\end{array}$ \\
\hline home2008 & $\begin{array}{c}-0.11 \\
(0.109)\end{array}$ & $\begin{array}{c}0.19 \\
(0.119)\end{array}$ & $\begin{array}{l}1.15^{* * * *} \\
(0.1)\end{array}$ & $\begin{array}{c}1.54^{* * * *} \\
(0.085)\end{array}$ & $\begin{array}{c}1.62^{* * *} \\
(0.083)\end{array}$ & $\begin{array}{c}2.03^{* * *} \\
(0.099)\end{array}$ & $\begin{array}{l}2.05^{* * *} \\
(0.102)\end{array}$ & $\begin{array}{c}1.72 * * * \\
(0.083)\end{array}$ \\
\hline home2009 & $\begin{array}{c}0.038 \\
(0.108)\end{array}$ & $\begin{array}{c}0.32^{* * *} \\
(0.119)\end{array}$ & $\begin{array}{l}1.25^{* * *} \\
(0.101)\end{array}$ & $\begin{array}{c}1.58^{* * * *} \\
(0.084)\end{array}$ & $\begin{array}{c}1.69 * * * \\
(0.082)\end{array}$ & $\begin{array}{c}2.07^{* * *} \\
(0.098)\end{array}$ & $\begin{array}{l}1.92^{* * *} \\
(0.105)\end{array}$ & $\begin{array}{c}1.75^{* * * *} \\
(0.081)\end{array}$ \\
\hline home2010 & $\begin{array}{l}-0.42^{* * * *} \\
(0.108)\end{array}$ & $\begin{array}{c}-0.11 \\
(0.119)\end{array}$ & $\begin{array}{c}0.98^{* * *} \\
(0.102)\end{array}$ & $\begin{array}{c}1.32^{* * *} \\
(0.086)\end{array}$ & $\begin{array}{c}1.52^{* * *} \\
(0.084)\end{array}$ & $\begin{array}{c}1.92^{* * *} \\
(0.098)\end{array}$ & $\begin{array}{l}1.43^{* * *} \\
(0.103)\end{array}$ & $\begin{array}{l}1.27^{* * * *} \\
(0.08)\end{array}$ \\
\hline home2011 & $\begin{array}{l}-0.62^{* * *} \\
(0.109)\end{array}$ & $\begin{array}{c}-0.28^{* *} \\
(0.119)\end{array}$ & $\begin{array}{l}0.75^{* * *} \\
(0.103)\end{array}$ & $\begin{array}{c}1.1^{* * *} \\
(0.087)\end{array}$ & $\begin{array}{c}1.42^{* * *} \\
(0.085)\end{array}$ & $\begin{array}{c}1.83^{* * *} \\
(0.097)\end{array}$ & $\begin{array}{c}1^{* * *} \\
(0.104)\end{array}$ & $\begin{array}{c}0.86 \text { **** } \\
(0.086)\end{array}$ \\
\hline
\end{tabular}

Notes: ${ }^{* *}$ and ${ }^{* *}$ mean the $1 \%$ and $5 \%$ significance level, respectively. The standard errors are listed in parenthesis.

Source: Author's calculation 
Turning to the individual scores, border effect parameters of the Mátyás (1997) specification are listed in Table 3 while those of the Baldwin and Taglioni (2006) specification are presented in Table 4. It is outstanding that Hungary has the lowest point estimates both in the beginning and in the end of the period regardless which model-specification is estimated. If country pair heterogeneity is neglected (Table 3) the excessive preference of domestic trade partners in 1995 seems to be $11.4\left(\mathrm{e}^{2.43}\right)$ or $12.2\left(\mathrm{e}^{2.5}\right)$ fold for Hungary versus $14.7\left(\mathrm{e}^{2.69}\right)$ or $20.1\left(\mathrm{e}^{3}\right)$ fold for Czechia, $22\left(\mathrm{e}^{3.09}\right)$ or $28.2\left(\mathrm{e}^{3.34}\right)$ fold for Poland and $35.5\left(\mathrm{e}^{3.57}\right)$ or $23.3\left(\mathrm{e}^{3.15}\right)$ fold for Slovakia. Except for some years (for instance 1996 for the Czech Republic and Slovakia, and 2003 for the Czech Republic) border effects were decreasing continuously in each Visegrad country until the dawn of the world financial and economic crises (2008).

This implies that regarding international trade the integration process of these countries was successful. Nonetheless, after trust wavered in the international financial system firms rather turned their attention to domestic markets. This tendency is reflected in Table 3, too. Border effect parameters stopped falling in 2008 and suddenly jumped in 2009 . Firms thought that domestic markets could function as a safety net against the crisis. The aversion of international commodity markets, however, did not take a long time. In 2010 home bias coefficients started to shrink again. Moreover, in 2011 they reached their absolute minimum level in each country. According to this model specification Hungary already preferred foreign business partners to domestic ones in 2011, while the other three countries still showed some excessive favour towards national partners. Depending on the estimator the volume of Hungarian intra-national trade flows was $46.2 \%\left(\mathrm{e}^{-0.62}-1\right)$ or $25.4 \%\left(\mathrm{e}^{-0.28}-1\right)$ lower than predicted by the gravity model. Meanwhile, the Czech Republic, Poland and Slovakia traded within their borders $2.12\left(\mathrm{e}^{0.75}\right)$ or $3\left(\mathrm{e}^{1.1}\right)$ times, $4.14\left(\mathrm{e}^{1.42}\right)$ or $6.23\left(\mathrm{e}^{1.83}\right)$ times and $2.72\left(\mathrm{e}^{1}\right)$ or $2.36\left(\mathrm{e}^{0.86}\right)$ times more respectively than they would with an EU member country of the same economic size, located exactly as far as domestic producers and consumers are from each other in these countries.

Looking at Table 4 one can study the evolution of individual border effects when country pair heterogeneity is accounted for. Note that border effect variables for 1995 are omitted in order ensure that the estimate exists. The extremely low negative values should be carefully interpreted as suggested above. Again the Hungarian economy looks the most open one to foreign markets with the smallest home bias followed by Slovakia. In contrast with the Mátyás (1997) specification (Table 3) Poland is not unambiguously the most biased economy as its parameters are similar to those of the Czech Republic. Regarding the model specification a'la Baldwin and Taglioni (2006) in the beginning of the period the border effect was not significantly different from zero in any of the four countries, while in 2011 the volume of their domestic trade was just 4.6-20.4\% of what would be predicted by the gravity model. It is also remarkable that border effects estimated by PPML are higher everywhere supporting the presumption that OLS underestimates the size of border effect. Although the results in Table 3 and those in Table 4 look contradictory, one useful conclusion is true for both of them. Throughout the period of 1995-2011 the Hungarian, Czech, Polish and Slovak economy became less and less biased towards domestic trading 
partners. Thus their commodity markets were connecting annually more and more tightly to the Single Market thanks to favourable tendencies on the world market and their EU accession in 2004.

Table 4 | Border Effect Coefficients Broken down by Country (Baldwin and Taglioni (2006) specification)

\begin{tabular}{|c|c|c|c|c|c|c|c|c|}
\hline \multirow{2}{*}{$\begin{array}{l}\text { Dep. var.: } \\
\text { In } X_{i j}(\mathrm{OLS}) ; \\
X_{i j}(\mathrm{PPML})\end{array}$} & \multicolumn{2}{|c|}{ Hungary } & \multicolumn{2}{|c|}{ Czech Republic } & \multicolumn{2}{|c|}{ Poland } & \multicolumn{2}{|c|}{ Slovakia } \\
\hline & $\begin{array}{l}\text { (1) } \\
\text { OLS }\end{array}$ & $\begin{array}{c}\text { (2) } \\
\text { PPML }\end{array}$ & $\begin{array}{l}\text { (3) } \\
\text { OLS }\end{array}$ & $\begin{array}{c}\text { (4) } \\
\text { PPML }\end{array}$ & $\begin{array}{l}\text { (5) } \\
\text { OLS }\end{array}$ & $\begin{array}{c}\text { (6) } \\
\text { PPML }\end{array}$ & $\begin{array}{l}\text { (7) } \\
\text { OLS }\end{array}$ & $\begin{array}{c}\text { (8) } \\
\text { PPML }\end{array}$ \\
\hline home1995 & - & - & - & - & - & - & - & - \\
\hline home1996 & $\begin{array}{l}-0.06 \\
(0.190)\end{array}$ & $\begin{array}{l}-0.02 \\
(0.176)\end{array}$ & $\begin{array}{c}0.24 \\
(0.244)\end{array}$ & $\begin{array}{c}0.18 \\
(0.288)\end{array}$ & $\begin{array}{l}-0.24 \\
(0.219)\end{array}$ & $\begin{array}{l}-0.06 \\
(0.213)\end{array}$ & $\begin{array}{c}0.23 \\
(0.238)\end{array}$ & $\begin{array}{c}0.27 \\
(0.469)\end{array}$ \\
\hline home1997 & $\begin{array}{l}-0.48^{* * *} \\
(0.166)\end{array}$ & $\begin{array}{l}-0.73^{* * *} \\
(0.173)\end{array}$ & $\begin{array}{c}0.08 \\
(0.209)\end{array}$ & $\begin{array}{c}0.11 \\
(0.273)\end{array}$ & $\begin{array}{l}-0.22 \\
(0.185)\end{array}$ & $\begin{array}{l}-0.11 \\
(0.198)\end{array}$ & $\begin{array}{c}-0.43^{* *} \\
(0.218)\end{array}$ & $\begin{array}{l}-0.16 \\
(0.438)\end{array}$ \\
\hline home1998 & $\begin{array}{l}-0.85^{* * *} \\
(0.166)\end{array}$ & $\begin{array}{l}-0.97^{* * *} \\
(0.163)\end{array}$ & $\begin{array}{l}-0.15 \\
(0.198)\end{array}$ & $\begin{array}{l}-0.03 \\
(0.25)\end{array}$ & $\begin{array}{l}-0.25 \\
(0.18)\end{array}$ & $\begin{array}{l}-0.06 \\
(0.186)\end{array}$ & $\begin{array}{l}-0.36^{*} \\
(0.211)\end{array}$ & $\begin{array}{l}-0.19 \\
(0.403)\end{array}$ \\
\hline home1999 & $\begin{array}{c}-0.93^{* * *} \\
(0.17)\end{array}$ & $\begin{array}{l}-1.08^{* * *} \\
(0.157)\end{array}$ & $\begin{array}{l}-0.31 \\
(0.198)\end{array}$ & $\begin{array}{c}0.01 \\
(0.246)\end{array}$ & $\begin{array}{c}0.23 \\
(0.19)\end{array}$ & $\begin{array}{c}0.01 \\
(0.184)\end{array}$ & $\begin{array}{l}-0.36^{*} \\
(0.202)\end{array}$ & $\begin{array}{l}-0.18 \\
(0.396)\end{array}$ \\
\hline home2000 & $\begin{array}{l}-1.33^{* * *} \\
(0.161)\end{array}$ & $\begin{array}{l}-1.46^{* * *} \\
(0.155)\end{array}$ & $\begin{array}{l}-0.53^{* * *} \\
(0.184)\end{array}$ & $\begin{array}{l}-0.24 \\
(0.242)\end{array}$ & $\begin{array}{l}-0.32^{*} \\
(0.174)\end{array}$ & $\begin{array}{c}-0.13 \\
(0.181)\end{array}$ & $\begin{array}{l}-0.56^{* * *} \\
(0.196)\end{array}$ & $\begin{array}{c}-0.3 \\
(0.389)\end{array}$ \\
\hline home2001 & $\begin{array}{l}-1.45^{* * *} \\
(0.154)\end{array}$ & $\begin{array}{l}-1.4^{* * *} \\
(0.15)\end{array}$ & $\begin{array}{l}-0.5^{* * *} \\
(0.184)\end{array}$ & $\begin{array}{l}-0.34 \\
(0.238)\end{array}$ & $\begin{array}{c}-0.33^{*} \\
(0.17)\end{array}$ & $\begin{array}{l}-0.17 \\
(0.178)\end{array}$ & $\begin{array}{l}-0.91 \text { *** } \\
(0.194)\end{array}$ & $\begin{array}{l}-0.53 \\
(0.378)\end{array}$ \\
\hline home2002 & $\begin{array}{l}-1.41^{* * *} \\
(0.158)\end{array}$ & $\begin{array}{l}-1.4^{* * *} \\
(0.148)\end{array}$ & $\begin{array}{l}-0.89^{* * *} \\
(0.184)\end{array}$ & $\begin{array}{c}-0.64^{* * *} \\
(0.233)\end{array}$ & $\begin{array}{c}-0.43^{* *} \\
(0.185)\end{array}$ & $\begin{array}{l}-0.33^{*} \\
(0.172)\end{array}$ & $\begin{array}{l}-0.98^{* * *} \\
(0.189)\end{array}$ & $\begin{array}{l}-0.57 \\
(0.378)\end{array}$ \\
\hline home2003 & $\begin{array}{l}-1.57^{* * *} \\
(0.156)\end{array}$ & $\begin{array}{l}-1.46^{* * *} \\
(0.145)\end{array}$ & $\begin{array}{l}-0.75^{* * * *} \\
(0.18)\end{array}$ & $\begin{array}{l}-0.5^{* *} \\
(0.229)\end{array}$ & $\begin{array}{l}-0.7^{* * *} \\
(0.168)\end{array}$ & $\begin{array}{l}-0.55^{* * *} \\
(0.171)\end{array}$ & $\begin{array}{l}-1.23^{* *} \\
(0.183)\end{array}$ & $\begin{array}{l}-0.89 * * \\
(0.373)\end{array}$ \\
\hline home2004 & $\begin{array}{c}-1.77^{* * *} \\
(0.17)\end{array}$ & $\begin{array}{l}-1.62^{* * *} \\
(0.144)\end{array}$ & $\begin{array}{c}-0.86^{* *} \\
(0.181)\end{array}$ & $\begin{array}{l}-0.72^{* * *} \\
(0.227)\end{array}$ & $\begin{array}{l}-1.05^{* * *} \\
(0.166)\end{array}$ & $\begin{array}{l}-0.84^{* * *} \\
(0.168)\end{array}$ & $\begin{array}{l}-1.47^{* * *} \\
(0.187)\end{array}$ & $\begin{array}{l}-1.05^{* * *} \\
(0.373)\end{array}$ \\
\hline home2005 & $\begin{array}{c}-1.93^{* * *} \\
(0.16)\end{array}$ & $\begin{array}{l}-1.69^{* * *} \\
(0.139)\end{array}$ & $\begin{array}{l}-1.13^{* * * *} \\
(0.186)\end{array}$ & $\begin{array}{l}-0.87^{* * *} \\
(0.225)\end{array}$ & $\begin{array}{l}-1.13^{* * * *} \\
(0.17)\end{array}$ & $\begin{array}{l}-0.97^{* * *} \\
(0.166)\end{array}$ & $\begin{array}{l}-1.56^{* * *} \\
(0.198)\end{array}$ & $\begin{array}{l}-1.18^{* * *} \\
(0.369)\end{array}$ \\
\hline home2006 & $\begin{array}{l}-2.29^{* * * *} \\
(0.158)\end{array}$ & $\begin{array}{l}-2.1 * * * \\
(0.141)\end{array}$ & $\begin{array}{l}-1.33^{* * *} \\
(0.189)\end{array}$ & $\begin{array}{l}-0.99^{* * * *} \\
(0.226)\end{array}$ & $\begin{array}{l}-1.31^{* * *} \\
(0.169)\end{array}$ & $\begin{array}{l}-1.19^{* * *} \\
(0.166)\end{array}$ & $\begin{array}{l}-1.83^{* * *} \\
(0.197)\end{array}$ & $\begin{array}{l}-1.36^{* * *} \\
(0.369)\end{array}$ \\
\hline home2007 & $\begin{array}{l}-2.41^{* * *} \\
(0.158)\end{array}$ & $\begin{array}{l}-2.31^{\text {*** }} \\
(0.141)\end{array}$ & $\begin{array}{l}-1.37^{* * *} \\
(0.197)\end{array}$ & $\begin{array}{l}-1.08^{* * *} \\
(0.228)\end{array}$ & $\begin{array}{l}-1.41^{* * *} \\
(0.171)\end{array}$ & $\begin{array}{l}-1.22^{* * *} \\
(0.166)\end{array}$ & $\begin{array}{l}-2.18^{* * *} \\
(0.201)\end{array}$ & $\begin{array}{l}-1.58^{* * *} \\
(0.369)\end{array}$ \\
\hline home2008 & $\begin{array}{l}-2.46^{* * *} \\
(0.166)\end{array}$ & $\begin{array}{l}-2.42^{* * *} \\
(0.139)\end{array}$ & $\begin{array}{l}-1.33^{* * *} \\
(0.205)\end{array}$ & $\begin{array}{l}-1.08^{* * *} \\
(0.229)\end{array}$ & $\begin{array}{l}-1.59^{* * *} \\
(0.182)\end{array}$ & $\begin{array}{l}-1.31^{* * *} \\
(0.167)\end{array}$ & $\begin{array}{l}-2.11^{* * *} \\
(0 . .216)\end{array}$ & $\begin{array}{l}-1.46^{* * *} \\
(0 . .371)\end{array}$ \\
\hline home2009 & $\begin{array}{l}-2.36^{* * *} \\
(0.164)\end{array}$ & $\begin{array}{l}-2.23^{* * *} \\
(0.142)\end{array}$ & $\begin{array}{l}-1.19^{* * *} \\
(0.197)\end{array}$ & $\begin{array}{l}-1.01^{* * *} \\
(0.225)\end{array}$ & $\begin{array}{l}-1.6^{* * *} \\
(0.176)\end{array}$ & $\begin{array}{l}-1.36^{* * *} \\
(0.166)\end{array}$ & $\begin{array}{l}-1.99^{* * *} \\
(0.216)\end{array}$ & $\begin{array}{l}-1.47^{* * *} \\
(0.371)\end{array}$ \\
\hline home2010 & $\begin{array}{c}-2.78^{* * *} \\
(0.17)\end{array}$ & $\begin{array}{l}-2.7^{* * *} \\
(0.14)\end{array}$ & $\begin{array}{l}-1.6^{* * *} \\
(0.201)\end{array}$ & $\begin{array}{l}-1.33^{* * *} \\
(0.225)\end{array}$ & $\begin{array}{l}-1.7^{* * *} \\
(0.178)\end{array}$ & $\begin{array}{l}-1.49^{* * *} \\
(0.165)\end{array}$ & $\begin{array}{l}-2.55^{* * *} \\
(0.215)\end{array}$ & $\begin{array}{l}-2.01^{* * *} \\
(0.373)\end{array}$ \\
\hline home2011 & $\begin{array}{l}-2.91^{* * *} \\
(0.163)\end{array}$ & $\begin{array}{l}-2.9^{* * *} \\
(0.141)\end{array}$ & $\begin{array}{l}-1.87^{* * *} \\
(0.199)\end{array}$ & $\begin{array}{l}-1.62^{* * *} \\
(0.226)\end{array}$ & $\begin{array}{l}-1.86^{* * *} \\
(0.173)\end{array}$ & $\begin{array}{l}-1.59 * * * \\
(0.166)\end{array}$ & $\begin{array}{l}-3.09 * * * \\
(0.208)\end{array}$ & $\begin{array}{l}-2.5^{* * *} \\
(0.372)\end{array}$ \\
\hline
\end{tabular}

Notes: ${ }^{* *},{ }^{* *},{ }^{*}$ mean the $1 \%, 5 \%$ and $10 \%$ significance level, respectively. The standard errors are listed in parenthesis.

Source: Author's calculation 
Justifying why individual border effects are heterogeneous in the region can be the subject of further studies, but an explanation can be provided for the relatively small border effect values in case of Hungary that may distinguish the country from its Visegradian partners. In the surrounding of a well-functioning world economy that characterized almost every year of the pre-crisis period the volume of domestic trade flows has to increase dynamically together with that of international trade flows. Studying Figure 1 one can observe this phenomenon in case of the Czech, Slovak and Polish economy, particularly after the turn of the millennium up to the explosion of the crisis. The trend of the volume of Hungarian domestic trade, however, showed stagnation and even some decline that could come from two different sources. First, despite the economic boom domestic demand could not increase pervasively. Furthermore, the huge investments of multinational companies have not resulted in enough positive spillover effects. Both Bosco (2001) and Békés et al. (2009) found that just the most productive Hungarian firms could benefit from the presence of multinationals and become more competitive. As a result, domestic firms were hardly able to enter supply chains. For instance Tóth (1998) highlighted that large affiliates, especially those with full or major foreign ownership, tend to purchase intermediate sources from welltried foreign partners instead of involving Hungarian firms into the production network.

Figure 1 | Evolution of Intranational Trade Flows in the Visegrad Countries (1995 = 100)

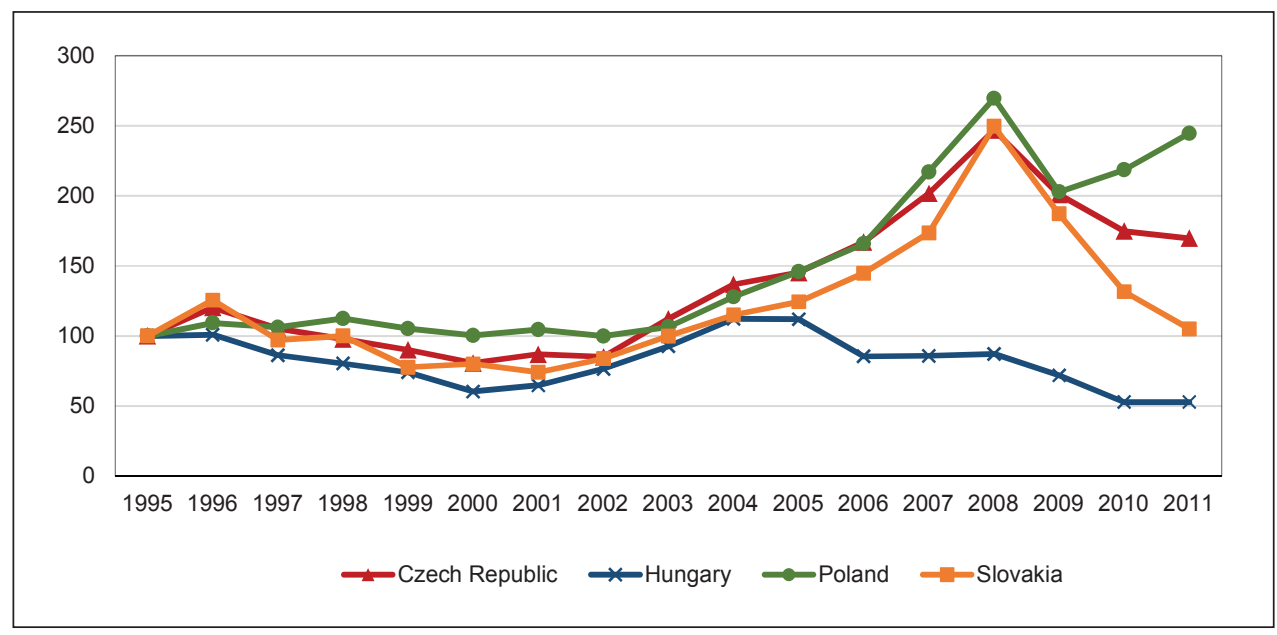

Source: own calculations using data from the World Development Indicators and World Input-Output databases.

The OECD TiVA statistics also underline these facts. According to them the Hungarian economy performed the smallest domestic value added. During the examined period the foreign value content of gross export was $65 \%$ on average compared to $64 \%$ in Slovakia, $63 \%$ in the Czech Republic and 58\% in Poland.

According to these facts the following consequence can be drawn in our case. Hungary established closer international trade relations at the expense of the economic activity of its 
domestic market. Meanwhile, the decline of Czech, Polish and even Slovak border effect was accompanied by a convincing growth of domestic trade after the early 2000 s.

\section{Conclusion}

The aim of this paper was to examine the evolution of border effect in the Visegrad countries both on an average and an individual country-level. In order to get robust results two different model specifications and two different estimators are compared, which leads to some important conclusions. First, the size of border effect fairly depends on, while the evolution of that seems to be not sensitive to the specification as well as the estimator chosen by the researcher. Second, predicting the model with time invariant country pair dummies yields unconventional (negative) border effect coefficients far from the positive and significant ones with large magnitude as in the majority of earlier studies. This suggests that the presence of border effect on today's globalized world market can be largely explained by the heterogeneity of country pairs. Namely, due to different social, political, cultural and business patterns firms trade otherwise with firms in different countries and especially with those of the same nationality. The decreasing trend of border effect coefficients interrupted by the crisis just for a short time implies that the Visegrad countries successfully joined the European trade network. Looking at the years around the EU accession of the countries one cannot observe any sudden drop in the home bias parameters, which demonstrates the notion that the trade integration process of the countries into the European Union started well before the ratification of the agreement. As far as individual border effects are concerned, Hungary seems to be the most integrated Visegrad country having the smallest point estimates on border effect variables, respectively. Although the Czech Republic, Slovakia and Poland look to some extent more biased towards domestic partners their deepening market integration process is also traceable year by year.

\section{Appendix}

Descriptive Statistics of the Main Country Pair Variables (sample for OLS)

\begin{tabular}{|l|c|c|c|c|c|}
\hline Variable & Observations & Mean & Std. Dev. & Min & Max \\
\hline In $\boldsymbol{i j}_{\boldsymbol{i j}}$ & 3,256 & 19.659 & 2.312 & 10.774 & 26.372 \\
\hline $\operatorname{InD}_{\boldsymbol{i j}}$ & 3,256 & 6.807 & 0.686 & 4.295 & 7.863 \\
\hline adj $_{\boldsymbol{i j}}$ & 3,256 & 0.125 & 0.331 & 0 & 1 \\
\hline cur $_{\boldsymbol{i j}}$ & 3,256 & 0.027 & 0.163 & 0 & 1 \\
\hline home1995-home2011 & 3,256 & 0.0012 & 0.035 & 0 & 1 \\
\hline home $_{\mathbf{k}}$ 1995-home $_{\mathbf{k}} \mathbf{2 0 1 1}$ & 3,256 & 0.0003 & 0.018 & 0 & 1 \\
\hline
\end{tabular}

Source: Author's calculation 
Descriptive Statistics of the Main Country Pair Variables (sample for PPML)

\begin{tabular}{|c|c|c|c|c|c|}
\hline Variable & Observations & Mean & Std. Dev. & Min & Max \\
\hline$x_{i j}$ & 3,264 & 0.308 & 1.358 & 0 & 28.4 \\
\hline $\ln D_{i j}$ & 3,264 & -9.31 & 0.685 & -11.823 & -8.255 \\
\hline $\operatorname{adj}_{i j}$ & 3,264 & 0.125 & 0.331 & 0 & 1 \\
\hline cur $_{i j}$ & 3,264 & 0.027 & 0.163 & 0 & 1 \\
\hline home1995-home2011 & 3,264 & 0.0012 & 0.035 & 0 & 1 \\
\hline home $_{k}$ 1995-home 2011 & 3,264 & 0.0003 & 0.018 & 0 & 1 \\
\hline
\end{tabular}

Notes: Continuous variables are rescaled (original values divided by $10^{10}$ ) as the PPML estimator is not suitable for large values.

Source: Author's calculation

\section{List of Countries in the Sample}

\begin{tabular}{|l|l|l|l|}
\hline Austria & Finland & Latvia & Slovak Republic (Slovakia) \\
\hline Belgium-Luxembourg & France & Lithuania & Slovenia \\
\hline Bulgaria & Germany & Malta & Spain \\
\hline Cyprus & Greece & The Netherlands & Sweden \\
\hline Czech Republic & Hungary & Poland & The United Kingdom \\
\hline Denmark & Ireland & Portugal & \\
\hline Estonia & Italy & Romania & \\
\hline
\end{tabular}

Notes: GDP (whole period), population (whole period) and export (after 1999) data for Belgium-Luxembourg is calculated as sums of Belgian and Luxembourgish values. Distances where Belgium-Luxembourg is country $i$ or $j$ are computed as population weighted averages of the distance between Belgium and the particular country and Luxembourg and the particular country. Countries in italics are the countries of interest, that is, the members of the Visegradian group.

Source: Author's calculation

\section{References}

Anderson, J. E. (1979). A Theoretical Foundation for the Gravity Equation. The American Economic Review, 69(1), 106-116.

Anderson, J. E., van Wincoop, E. (2003). Gravity with Gravitas: A Solution to the Border Puzzle. The American Economic Review, 93(1), 170-192, https://doi. org/10.1257/000282803321455214

Andresen, M. A. (2010). The Geography of the Canada-United States Border Effect. Regional Studies, 44(5), 579-594, https://doi.org/10.1080/00343400802508794

Baldwin, R., Taglioni, D. (2006). Gravity for Dummies and Dummies for Gravity Equations.

National Bureau of Economic Research. Cambridge Working Paper No. 12516, https://doi. org/10.3386/w12516 
Balta, N., Delgado, J. (2009). Home Bias and Market Integration in the EU. CESifo Economic Studies, 55(1), 110-144. https://doi.org/10.1093/cesifo/ifn037

Baier, S. L., Bergstrand, J. H. (2009). Bonus Vetus OLS: A Simple Method for

Approximating International Trade-Cost Effects Using the Gravity Equation. Journal of International Economics, 77(1), 77-85, https://doi.org/10.1016/j.jinteco.2008.10.004

Békés, G., Kleinert, J., Toubal, F. (2009). Spillovers from Multinationals to Heterogeneous Domestic Firms: Evidence from Hungary. The World Economy, 32(10), 1408-1433, https:// doi.org/10.1111/j.1467-9701.2009.01179.x

Bergstrand, J. H. (1985). The Gravity Equation in International Trade: Some Microeconomic Foundations and Empirical Evidence. The Review of Economics and Statistics, 67(3), 474-481, https://doi.org/10.2307/1925976

Bergstrand, J. H. (1989). The Generalized Gravity Equation, Monopolistic Competition, and the Factor Proportions Theory in International Trade. The Review of Economics and Statistics, 71(1), 143-153, https://doi.org/10.2307/1928061

Bosco, M. G. (2001). Does FDI Contribute to Technological Spillovers and Growth? A Panel Data Analysis of Hungarian Firms. Transnational Corporations, 10(1), 43-68.

Chen, N. (2004). Intra-national versus International Trade in the European Union: Why do National Borders Matter? Journal of International Economics, 63(1), 93-118. https://doi. org/10.1016/S0022-1996(03)00042-4

Cheng, I-H., Wall, H. J. (2005). Controlling for Heterogeneity in Gravity Models of Trade and Integration. Federal Reserve Bank of St. Louis Review, 87(1), 49-64, https://doi.org/10.3886/ icpsr01313.v1

Cheptea, A. (2010). Border Effects and East-West Integration. Smart Lereco Working Paper No. 10-15, 1-26.

Coughlin, C. C., Novy, D. (2013). Is the International Border Effect Larger than the Domestic Border Effect? Evidence from U. S. Trade. CESifo Economic Studies, 59(2), 249-276, https:// doi.org/10.1093/cesifo/ifs002

Deardorff, A.V. (1998). Determinants of Bilateral Trade. Does Gravity Work in a Neoclassical World? In: The Regionalization of the World Economy. Chicago, University of Chicago Press. ISBN 0-226-25995-1, pp. 7-32.

Eaton, J., Kortum, S. (2002). Technology, Geography and Trade. Econometrica, 70(5), 1741-1779, https://doi.org/10.1111/1468-0262.00352

Feenstra, R. C. (2002). Border Effects and the Gravity Equation: Consistent Methods for Estimation. Scottish Journal of Political Economy, 49(5), 491-506, https://doi. org/10.1111/1467-9485.00244

Gil-Pareja, S., Martínez-Serrano, J.A., Llorca-Vivero, R., Oliver-Alonso, J. (2005). The Border Effect in Spain. The World Economy, 28(11), 1617-1631, https://doi. org/10.1111/j.1467-9701.2005.00749.x

Head, K., Mayer, T. (2000). Non-Europe: The Magnitude and Causes of Market Fragmentation in Europe. Weltwirtschaftliches Archiv, 136(2), 285-314, https://doi. org/10.1007/BF02707689

Head, K., Mayer, T. (2002). Illusory Border Effects: Distance Mismeasurement Inflates Estimates of Home Bias in Trade. Centre d'Etudes Prospectives et d'Informations Internationales (CEPII), Paris Working Paper No. 2002-01. 
Helliwell, J. F. (1998). How Much Do National Borders Matter? Washington, DC: Brookings Institution Press. ISBN 9780815735540.

Hilberry, R., Hummels, D. (2003). Intranational Home Bias: Some Explanations. The Review of Economics and Statistics, 85(4), 1089-1092, https://doi. org/10.1162/003465303772815970

Horváth, J., Rátfai, A., Döme, B. (2008). The Border Effect in Small Open Economies. Economic Systems, 32(1), 33-45, https://doi.org/10.1016/j.ecosys.2007.07.001

Krugman, P. (1980). Scale Economies, Product Differentiation and the Pattern of Trade. The American Economic Review, 70(5), 950-959.

Llano-Verduras, C., Minondo, A., Requena-Silvente, F. (2011). Is the Border Effect an Artefact of Geographical Aggregation? The World Economy, 34(10), 1171-1187. https://doi. org/10.1111/j.1467-9701.2011.01398.x

Mátyás, L. (1997). Proper Econometric Specification of the Gravity Model. The World Economy, 20(3), 363-368, https://doi.org/10.1111/1467-9701.00074

McCallum, J. (1995). National Borders Matter: Canada-U.S. Regional Trade Patterns. The American Economic Review, 85(3), 615-623.

Milimet, D. L., Osang, T. (2007). Do State Borders Matter for U.S. Intra-national Trade? The Role of History and Internal Migration. Canadian Journal of Economics, 40(1), 93-126, https:// doi.org/10.1111/j.1365-2966.2007.00401.x

Nitsch, V. (2000). National Borders and International Trade: Evidence from the European Union. Canadian Journal of Economics, 33(4), 1091-1105, https://doi.org/10.1111/0008-4085.00055

Obstfeld, M., Rogoff, K. (2001). The Six Major Puzzles in International Macroeconomics: Is There a Common Cause? NBER Macroeconomics Annual, 15, Cambridge: MIT press, 339-412, https://doi.org/10.2307/3585403

Pacchioli, C. (2011). Is the EU Internal Market Suffering from an Integration Deficit? Estimating the 'Home-bias Effect'. CEPS Working Document No. 348, May 2011, https://doi.org/10.2139/ ssrn. 1898602

Pásztor, Sz. (2014). The Economic Transformation of Borders in Central and Eastern Europe: The Case of Hungary and Its Eastern Borders. PhD dissertation, University of Debrecen, Debrecen. Retrieved: https://dea.lib.unideb.hu/dea/handle/2437/182110

Pöyhönen, P. (1963). A Tentative Model for the Volume of Trade between Countries. Weltwirtschaftliches Archiv, 90(1), 93-99.

Rose, A. K., van Wincoop, E. (2001). National Money as a Barrier to International Trade: The Real Case for Monetary Union, American Economic Review, 91(2), 386-390, https://doi. org/10.1257/aer.91.2.386

Samuelson, P. A. (1954). The Transfer Problem and Transport Costs, II: Analysis of Effects of Trade Impediments. The Economic Journal, 64(254), 264-289, https://doi.org/10.2307/2226834

Santos Silva, J. M. C, Tenreyro, S. (2006). The Log of Gravity. The Review of Economics and Statistics, 88(4), 641-658, https://doi.org/10.1162/rest.88.4.641

Tinbergen, J. (1962). Shaping the World Economy - Suggestions for an International Economic Policy. New York: Twentieth Century Fund.

Tóth, I. J. (1998). Market Links and Growth Capability of Enterprises in a Transforming Economy: The Case of Hungary, in: Csaba, L., ed., The Hungarion SME Sector Development in Comparative Perspective. Budapest: KOPINT-DATORG Foundation and CIPE/USAID, 29-60. 
Wei, S-J. (1996). Intra-national versus International Trade: How Stubborn Are Nations in Global Integration? National Bureau of Economic Research. Cambridge Working Paper No. 5531, https://doi.org/10.3386/w5531

Wolf, H. C. (2000). Intranational Home Bias in Trade. The Review of Economics and Statistics, 82(4), 555-563, https://doi.org/10.1162/003465300559046 